\title{
Do different species of grass-dwelling small Auchenorrhyncha (Homoptera) have private vibrational communication channels?
}

\author{
Есть ми у разных видов мелких цикадовых (Homoptera: \\ Auchenorrhyncha), зкивущих на травянистой растительности, \\ собственные каналы вибращионной коммуникации?
}

\author{
D.Yu. Tishechkin \\ A.Ю. Тишечкин
}

Department of Entomology, Faculty of Biology, M.V. Lomonosov Moscow State University, Vorobyevy Gory, Moscow, 119991 Russia. Email: macropsis@yandex.ru

Кафедра энтомологии Биологического факультета Московского государственного университета имени М.В. Ломоносова, Воробьевы Горы, Москва, 119991 Россия.

KEY WORDS: Homoptera, Auchenorrhyncha, vibrational signals, signal transmission, communication channels, acoustic isolation.

КЛЮЧЕВЫЕ СЛОВА: Ноmoptera, Auchenorrhyncha, вибрационные сигналы, передача сигналов, каналы связи, акустическая изоляция.

ABSTRACT. It has been found experimentally that under natural conditions in the communities of herbaceous plants transmission of substrate-borne vibrational signals of small Auchenorrhyncha from stem to stem is possible both via the stems or leaves and via the roots. As a result, individuals occurring on different plants can perceive the signals of each other. Consequently, in sympatric species of grass-dwelling Auchenorrhyncha differences in host specialization by no means always provide segregation of vibratory communication channels.

РЕЗЮМЕ. В естественных условиях в сообществах травянистых растений экспериментально доказана возможность передачи распространяющихся по субстрату вибрационных сигналов мелких цикадовых со стебля на стебель как при контакте надземных частей (стеблей или листьев), так и через корни. За счет этого насекомые, находящиеся на разных растениях, могут воспринимать сигналы друг друга. Таким образом, у симпатрических видов хортофильных цикадовых трофическая связь с разными видами растений далеко не всегда обеспечивает разделение каналов акустической связи.

\section{Introduction}

Small Auchenorrhyncha (Homoptera) use for intraspecific communication not sounds, but substrate-borne vibrational signals (songs). Such signals can spread over all branches of a plant up to the distance of 1-1.5 m (Michelsen et al., 1982), but cannot be transmitted from plant to plant unless the stems are in contact with each other. Since most Auchenorrhyncha are monophagous or oli- gophagous, at first glance it would seem that species dwelling on different host plants are bound to have isolated communication channels. Apparently, in forms feeding on trees and shrubs this is so indeed, but in grassdwelling species situation is different. First, male ready for copulation demonstrates so-called call-fly behaviour. It flies from one plant to another producing calling signals on each stem; in so doing it can sing both on host and nonhost plants [Tishechkin, 2007]. Second, in steppes, grasslands, etc. plants of different species usually contact with each other both by stems and roots.

It is evident from the laboratory experiments that under certain conditions transmission of insect vibrational signals via two stems touching each other is possible. It remains to be seen whether such transmission is sufficiently effective in nature, however. The objective of the present study is to ascertain if the transmission of leafhopper vibrational songs from plant to plant via the roots or stems is actually possible in grass thickets.

\section{Material and methods}

Vibratory signals were registered in nature by means of piezo-electric crystal gramophone cartridge connected to the microphone input of minidisk recorder Sony Walkman MZ-RH910 via the matching amplifier.

Gramophone cartridge was attached to selected plant to begin with. After that the insects collected immediately before the experiment in the same biotope or nearby were put on the plants near the stem to which the equipment was connected. A number of individuals have escaped, but the most part of specimens remained on adjacent plants and as a rule started singing in a few minutes. In 

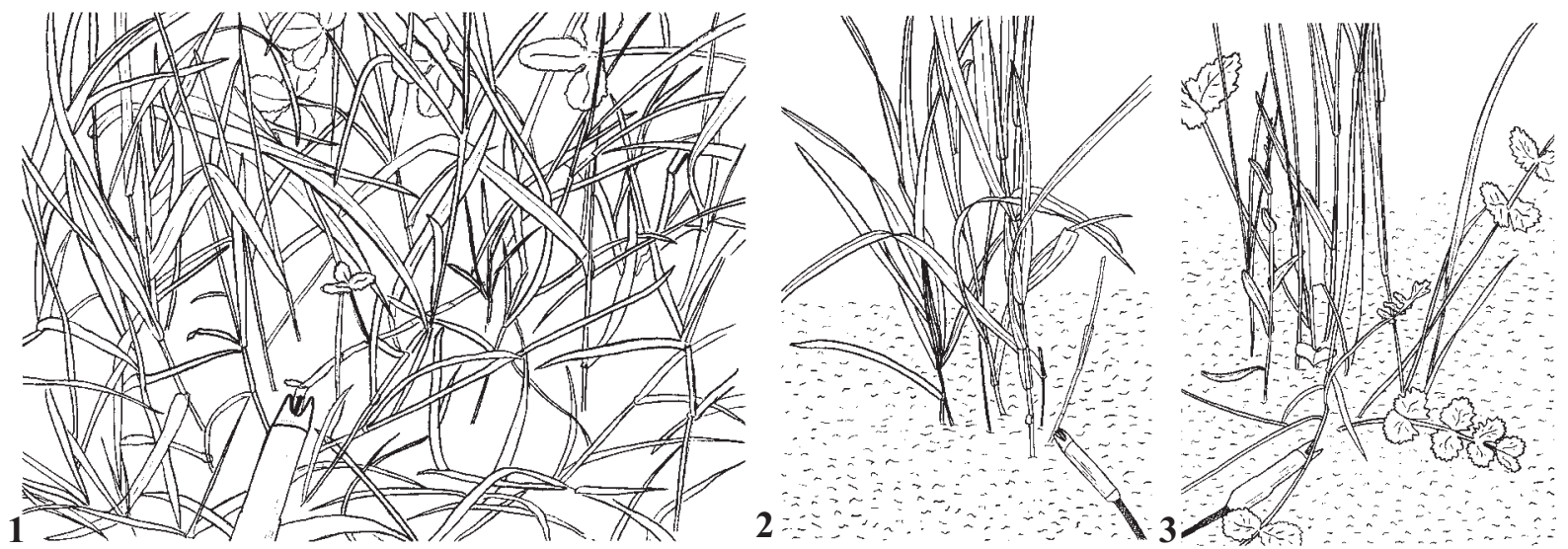

Figs. 1-3. Relative position of plants and vibrotransducer (gramophone cartridge) during field recordings; drawings from digital photographs. 1 - 1st set of experiments: recording of vibrational signals of small Auchenorrhyncha transmitted from stem to stem in the dense grass thickets (No. 1 in the Table), 2 - 2nd set of experiments: recording of vibrational signals transmitted from stem to stem of the same plant via the common root (No. 2 in the Table), 3 - 3rd set of experiments: recording of signals transmitted from one plant to another via the roots (No. 4 in the Table).

Рис. 1-3. Взаимное расположение растений и вибродатчика (головки звукоснимателя) во время записи сигналов в природе; рисунки с цифровых фотографий. 1 - 1-я серия экспериментов: запись вибрационных сигналов мелких цикадовых, передающихся со стебля на стебель в густых зарослях травы (№ 1 в таблице), 2 - 2-я серия экспериментов: запись вибрационных сигналов, передающихся со стебля на стебель одного и того же растения через общий корень (№ 2 в таблице), 3 - 3-я серия экспериментов: запись сигналов, передающихся с одного растения на другое через корни (№ 4 в таблице).

certain experiments all the grass was cut within ca. $30 \mathrm{~cm}$ from the recording point and only several intact stems were left. This enabled an easy control of a relative position of the stems and making clear photographs of plants on which the insects were singing.

All recordings were made in Moscow Area in June and July 2010. Drawings of a relative position of the plants on which the experiments were carried out are made from digital photographs taken after signal recordings. A number of individuals have escaped during re- cording; thus it was impossible to collect all insects again after completion of the experiment. For this reason two species of Delphacidae which signals are presented on oscillograms cannot be determined with certainty.

Since all experiments were performed under natural conditions, wind-induced noises and vibrations resulted from insect movements present on original recordings. On the most part of oscillograms the noises are partially removed by both low- and high-pass filters and only the frequencies within the range $180-3000 \mathrm{~Hz}$ were left.

Table. Data for signal recordings used in the paper Таблица. Данные об использованных в статье записях сигналов

\begin{tabular}{|c|c|c|c|c|}
\hline No. & Plants & Insects & $\begin{array}{l}\text { Air tempera- } \\
\text { ture during } \\
\text { recording, } \mathrm{C}\end{array}$ & $\begin{array}{l}\text { Recording sites } \\
\text { (all in Moscow Area) }\end{array}$ \\
\hline 1 & $\begin{array}{l}\text { Poa annua L. (Poaceae), Trifolium } \\
\text { repens L. (Fabaceae), plants up to } 10 \\
\text { cm high. }\end{array}$ & $\begin{array}{l}\text { Doratura stylata (Boh.), } \\
\text { Eupelix cuspidata (F.) } \\
\text { (Cicadellidae), and } \\
\text { Lepyronia coleoptrata } \\
\text { (L.) (Aphrophoridae) }\end{array}$ & 35 & $\begin{array}{l}\text { Voskresensk Distr., } \\
\text { env. Beloozerskiy } \\
\text { Town, lawn near the } \\
\text { summer cottage. }\end{array}$ \\
\hline 2 & $\begin{array}{l}\text { Undetermined grass species (Poaceae), } \\
\text { plants } 20-30 \mathrm{~cm} \text { high. }\end{array}$ & $\begin{array}{l}\text { Graphocraerus ventralis } \\
\text { (Fall.) (Cicadellidae) }\end{array}$ & $25-27$ & $\begin{array}{l}\text { Serpukhov Distr., } \\
\text { env. Pushchino-na- } \\
\text { Oke Town, meadow } \\
\text { on the river bank. }\end{array}$ \\
\hline 3 & $\begin{array}{l}\text { Undetermined grass species (Poaceae), } \\
\text { plants } 20-30 \mathrm{~cm} \text { high. }\end{array}$ & $\begin{array}{l}\text { Handianus flavovarius } \\
\text { (H.-S.) (Cicadellidae) and } \\
\text { several undetermined } \\
\text { species of Delphacidae }\end{array}$ & 27 & $\begin{array}{l}\text { Serpukhov Distr., } \\
\text { env. Luzhki Village, } \\
\text { forest glade. }\end{array}$ \\
\hline 4 & $\begin{array}{l}\text { Pimpinella saxifraga L. (Apiaceae), } \\
\text { Myosotis sp. (Boraginaceae), Rumex } \\
\text { sp. (Polygonaceae), Calamagrostis } \\
\text { epigeios (L.) Roth, and } 1-2 \\
\text { undetermined grass species (Poaceae), } \\
\text { plants up to } 30-40 \mathrm{~cm} \text { high. }\end{array}$ & $\begin{array}{l}\text { Handianus flavovarius } \\
\text { (H.-S.) and several } \\
\text { undetermined species of } \\
\text { Delphacidae }\end{array}$ & 24 & $\begin{array}{l}\text { Serpukhov Distr., } \\
\text { env. Luzhki Village, } \\
\text { dry meadow in the } \\
\text { upper flood-plain of } \\
\text { Oka River. }\end{array}$ \\
\hline
\end{tabular}


Results and discussion

The first set of experiments has been performed in the mixed thickets of Poa annua L. (Poaceae) and Trifolium repens L. (Fabaceae) (Fig. 1 and No.1 in the Table). Different plants of both species touched each other in many points. The gramophone cartridge was connected to the end of a crawling stem of $T$. repens deprived of the

4

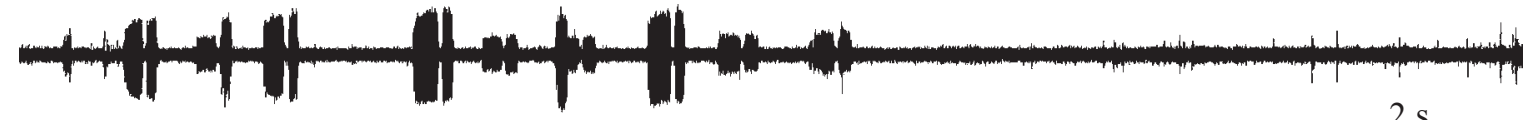

5

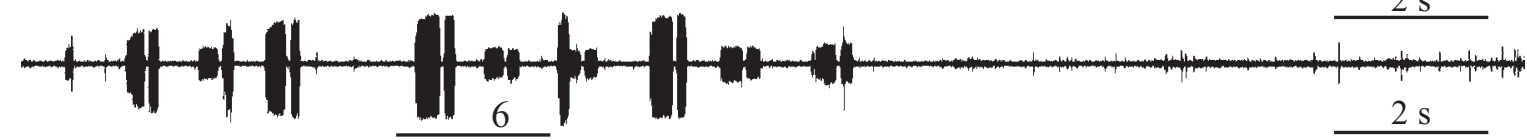

6

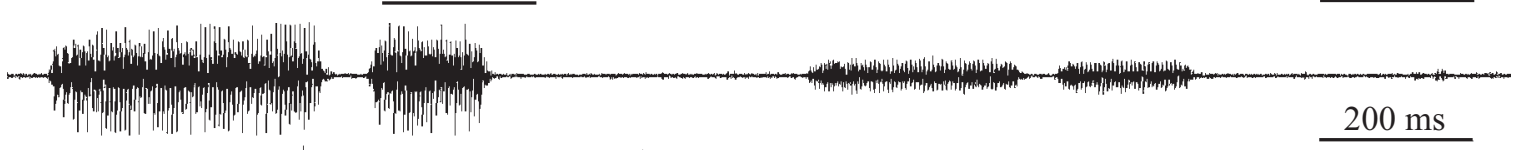

7

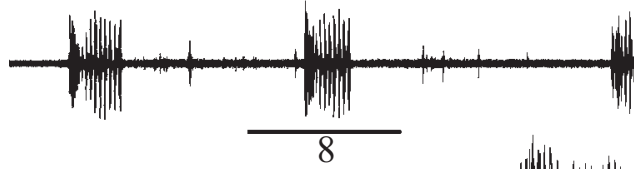

8

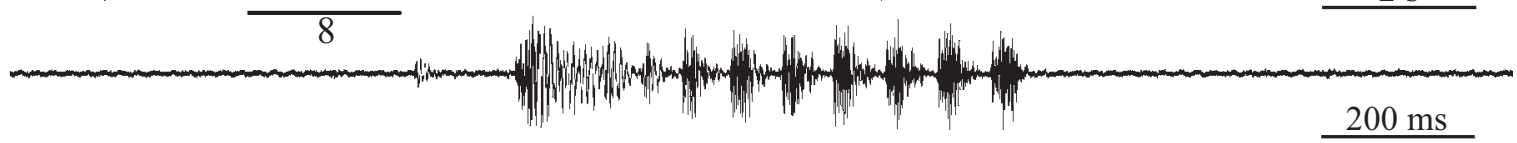

$2 \mathrm{~s}$

9

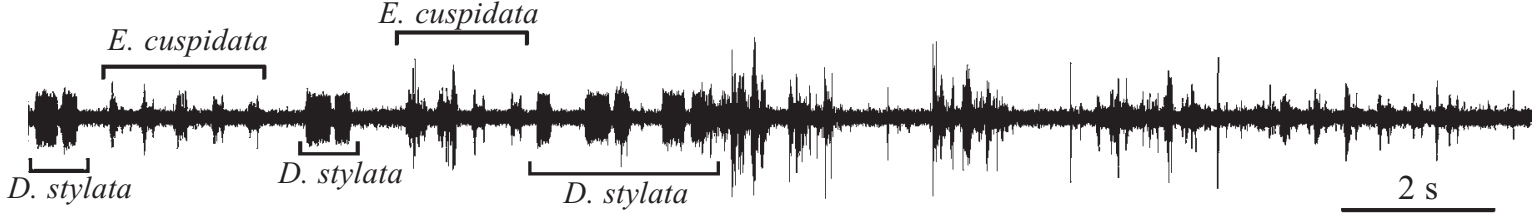

10

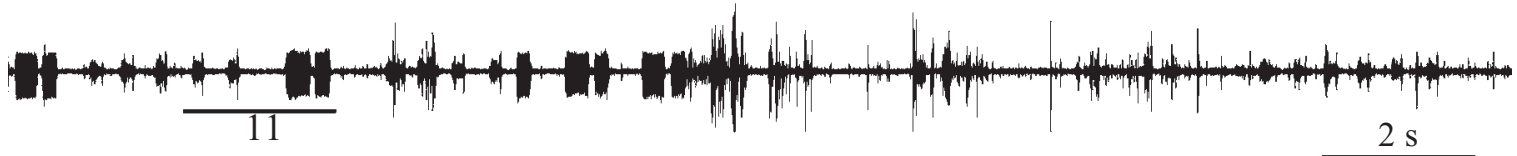

11
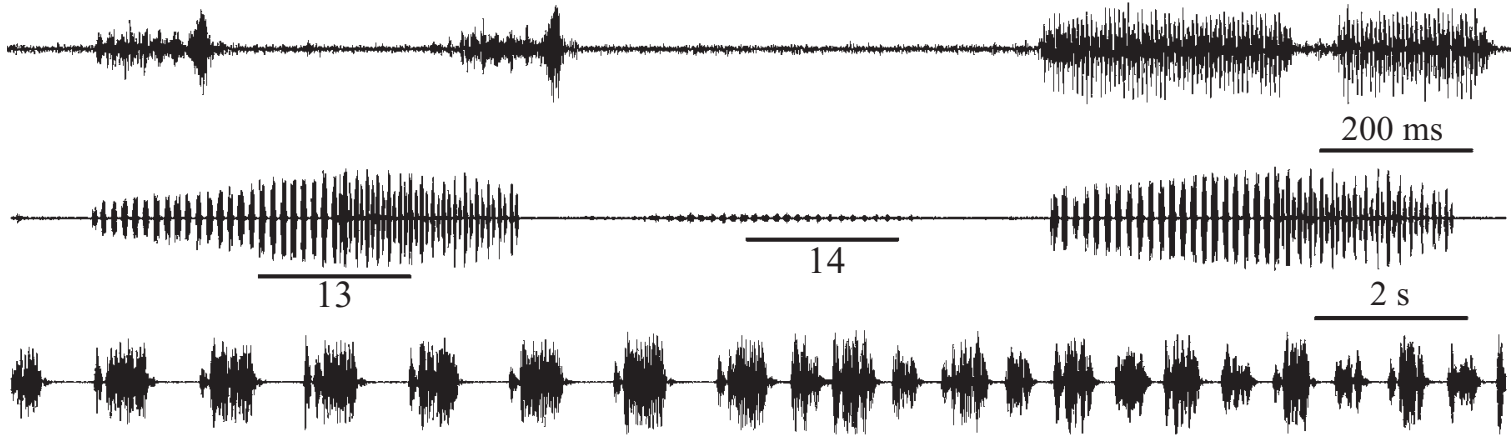

14

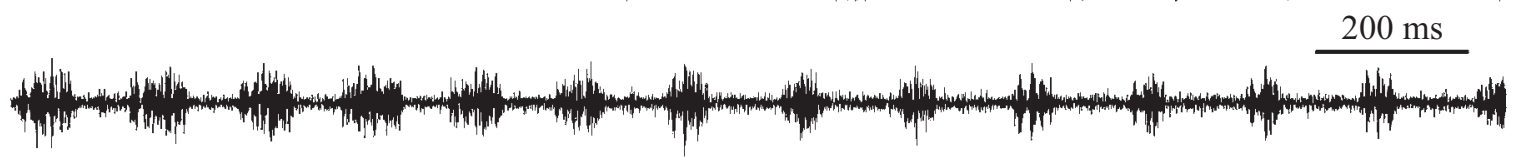

$200 \mathrm{~ms}$

Figs. 4-14. Oscillograms of vibrational calling signals of small Auchenorrhyncha. 4-11 - signals transmitted from stem to stem in the dense grass thickets (Fig. 1 and No. 1 in the Table): 4-6 - two males of Doratura stylata (Boh.) singing in different points, 7-8 - male of Lepyronia coleoptrata (L.), 9-11 - males of D. stylata and Eupelix cuspidata (F.); 12-14 - two males of Graphocraerus ventralis (Fall.) sitting in different points, the signals transmitted from stem to stem of the same plant via the common root (Fig. 2 and No. 2 in the Table). 4 and 7-9non-filtered signals, 5-6 and 10-14 - filtered signals, frequency band $180-3000 \mathrm{~Hz}$ is left. Faster oscillograms of the parts of signals indicated as "6", " 8 ", "11" and "13-14" are given under the same numbers.

Рис. 4-14. Осциллограммы вибрационных призывных сигналов мелких цикадовых. 4-11 - сигналы, передающиеся со стебля на стебель в густых зарослях травы (рис. 1 и № 1 в таблице): 4-6 - два самца Doratura stylata (Boh.), сидящие в разных точках, 7-8 самец Lepyronia coleoptrata (L.), 9-11 — самцы D. stylata и Eupelix cuspidata (F.); 12-14 — два самца Graphocraerus ventralis (Fall.), сидящие в разных точках, сигналы передаются со стебля на стебель одного и того же растения через общий корень (рис. 2 и № 2 в таблице). 4 и 7-9 - нефильтрованные сигналы, 5-6 и 10-14 - фильтрованные сигналы, оставлена полоса частот 180-3000 Гц. Фрагменты сигналов, помеченные цифрами “6”, "8”, “11” и “13-14”, представлены при большей скорости развёртки на осциллограммах под соответствующими номерами. 
most part of leaves. Two leafhopper species, Doratura stylata (Boheman, 1847) and Eupelix cuspidata (Fabricius, 1775) (Homoptera: Cicadellidae), both feeding on
Poaceae were used; in addition, the signals of a froghopper, Lepyronia coleoptrata (Linnaeus, 1758) (Homoptera: Aphrophoridae) were registered by accident.

15

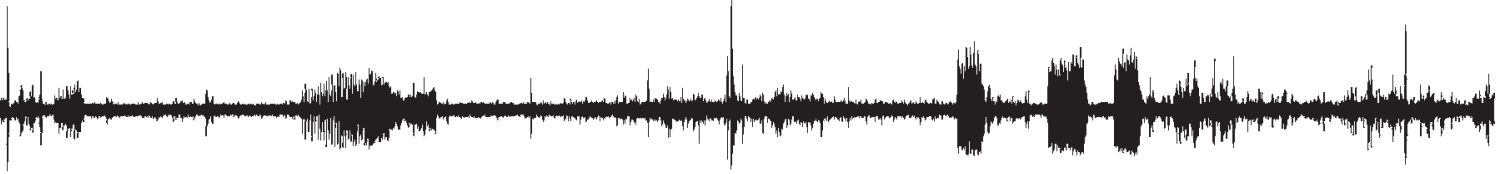

16

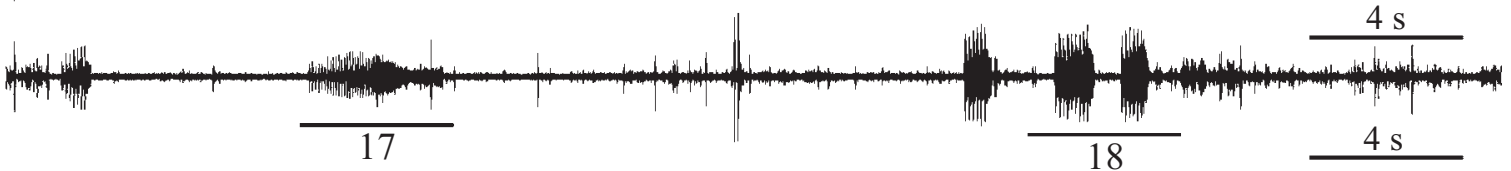

17

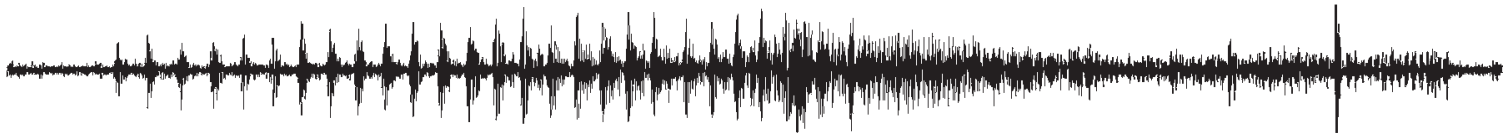

18

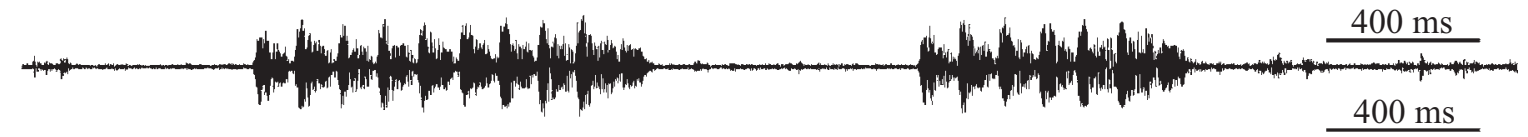

19

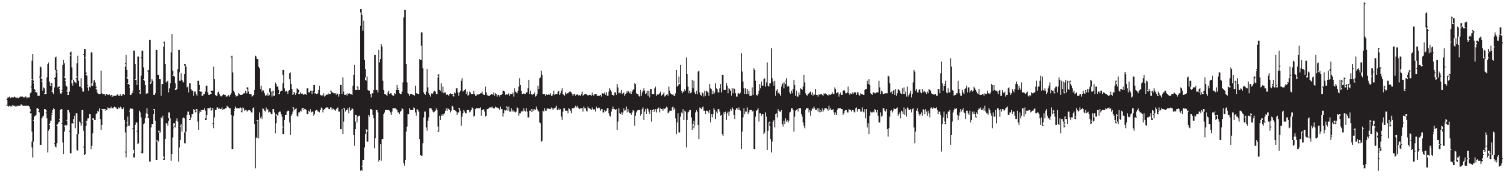

20

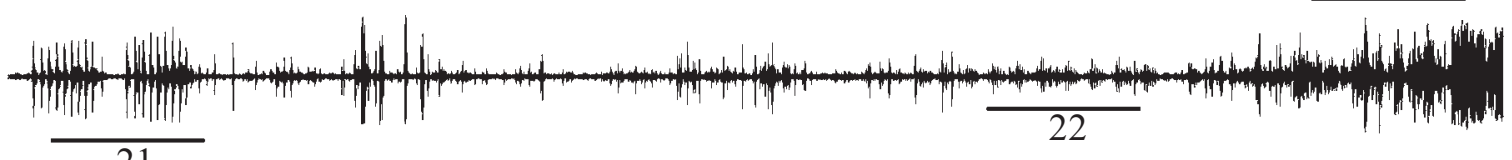

21

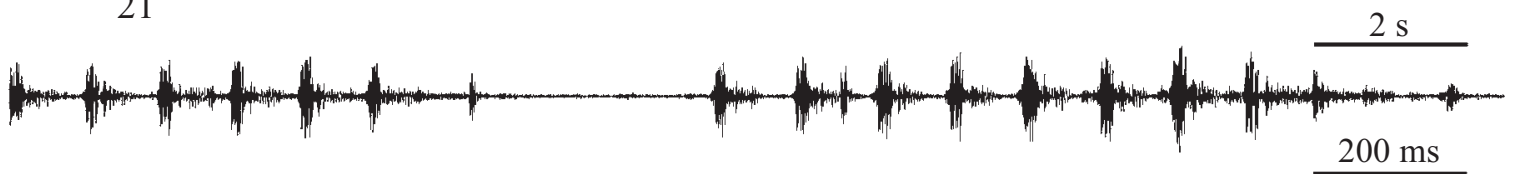

22
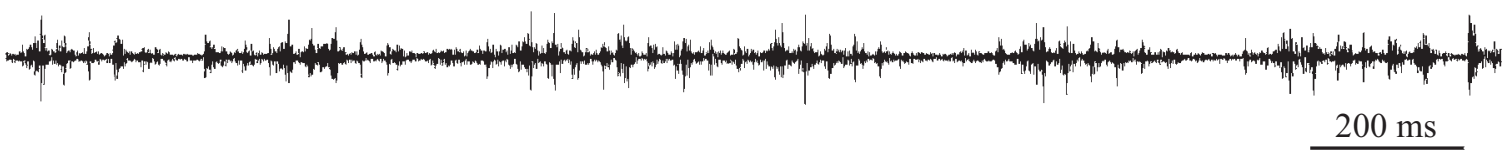

23

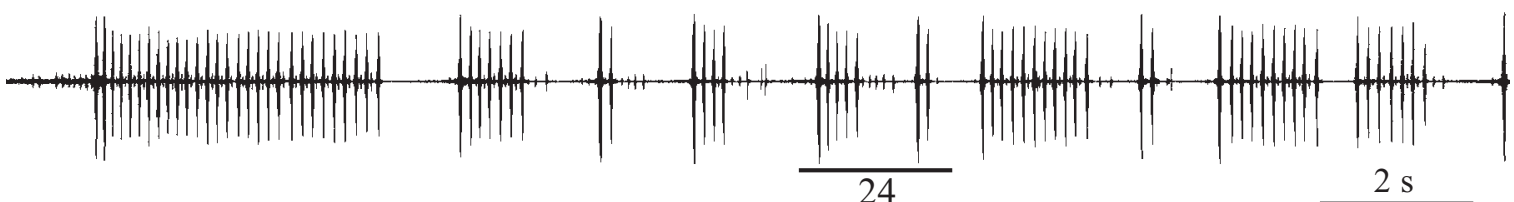

24

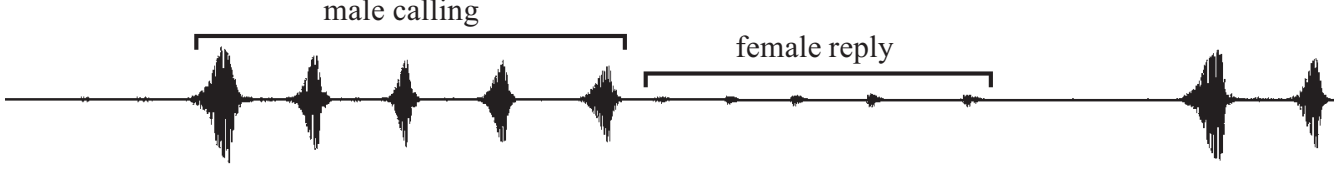

$200 \mathrm{~ms}$

Figs. 15-24. Oscillograms of vibrational calling signals of small Auchenorrhyncha. 15-18 - signals of two species transmitted from stem to stem of the same plant via the common root (No. 3 in the Table): 17 - undetermined species of Delphacidae (evidently, Dicranotropis hamata (Boh.)), 18 - Handianus flavovarius (H.-S.); 19-22 - signals of two species transmitted from one plant to another via the roots (Fig. 3 and No. 4 in the Table): 21 - H. flavovarius, 22 - undetermined species of Delphacidae (evidently, Javesella dubia Kbm.); 23-24 - Alebra albostriella (Fall.), male calling and female reply signals. 15 and 19 - non-filtered signals, 16-18 and 20-24 - filtered signals, frequency band $180-3000 \mathrm{~Hz}$ is left. Faster oscillograms of the parts of signals indicated as "17-18", "21-22" and "24" are given under the same numbers.

Рис. 15-24. Осциллограммы вибрационных призывных сигналов мелких цикадовых. 15-18 - сигналы двух видов, передающиеся со стебля на стебель одного и того же растения через общий корень (№ 3 в таблице): 17 - не определенный вид Delphacidae (очевидно, Dicranotropis hamata (Boh.)), 18 - Handianus flavovarius (H.-S.); 19-22 — сигналы двух видов, передающиеся с одного растения на другое через корни (рис. 3 и № 4 в таблице): $21-$ H. flavovarius, 22 - не определенный вид Delphacidae (очевидно, Javesella dubia Kbm.); 23-24 - Alebra albostriella (Fall.), призывный сигнал самца и ответ самки. 15 и 19 - нефильтрованные сигналы, 16-18 и 2024 - фильтрованные сигналы, оставлена полоса частот 180-3000 Гц. Фрагменты сигналов, помеченные цифрами "17-18", "21-22" и “24", представлены при большей скорости развёртки на осциллограммах под соответствующими номерами 
Recordings of calling signals of three species listed were obtained easily and had good quality, i.e. signal/ noise ratio (Figs 4-11). Quite often the songs differed much from each other in amplitude (Figs 4-6). This is evidence that the signals registered were produced by males occurring in different points. It was impossible to see all insects in the thickets, but the specimens we have seen were sitting only on $P$. annua. We failed to find the male of $L$. coleoptrata, but the song recordered indicated that it was present somewhere nearby (Figs 7-8).

Thus we can conclude that transmission of insect vibrational signals from plant to plant in dense mixed thickets is possible without considerable attenuation of vibrations.

In the second set of experiments the possibility of signal transmission from stem to stem through the common root, i.e. without a contact of stems above the ground was tested. For this purpose a group of stems of the same plant was selected (No. 2 and 3 in the Table). In one case (Fig. 2 and No. 2 in the Table) all other plants growing nearby were cut. The gramophone cartridge was connected to the stem standing alone and cut about $6 \mathrm{~cm}$ above the ground. Either Graphocraerus ventralis (Fallén, 1806) from the family Cicadellidae (Figs. 12-14) or Handianus flavovarius (HerrichSchäffer, 1835) (Cicadellidae) and several undetermined species of Delphacidae (Figs 15-18) were used for signal recordings. Only signals produced by the specimens sitting on intact stems were registered; every insect jumping on the cut stem with the cartridge attached was immediately removed. In both cases the plant was withdrawn from the ground after recording to be certain that the stems are actually connected to each other by common root system.

Recordings made under such conditions had approximately the same signal/noise ratio as in the previous case. Moreover, sometimes the calling signals of males sitting on different stems alternated with short breaks (Figs 12-14). Since in most species of insects singing of one male stimulates acoustic activity of the other ones, it is reasonable to assume that the males occurring on different stems having the common root actually perceived the signals of each other.

In the third set of experiments we have made an attempt to ascertain if the signal produced on one plant can be transmitted to another one via the roots. For this purpose a group of plants of various species including Pimpinella saxifraga L. (Apiaceae), Myosotis sp. (Boraginaceae), Rumex sp. (Polygonaceae) and several grass species (Poaceae) was selected; all other plants growing around were cut (Fig. 3 and No. 4 in the Table). Gramophone cartridge was attached to the leaf petiole of $P$. saxifraga. A number of males of $H$. flavovarius and of several undetermined species of Delphacidae were put on the stems. After a while only individuals feeding on grasses (Poaceae) and Myosotis sp. remained; it must be emphasized that no insects were sitting on $P$. saxifraga.

The amplitude of signals registered under such conditions usually was somewhat lower than in the previous experiments (Figs 19-22). Occasionally the signals were masked by wind-induced noises, still for the most part they remained quite discernible both for human ear when translated via earphones, and on oscillograms without frequency filtration (Fig. 19).

Previously we have investigated communication during mating behaviour in a number of species of small Auchenorrhyncha. In most minute and slender forms, e.g. in Typhlocybinae (Cicadellidae) the amplitude of female reply signals sometimes was much lower than that of a male calling song (Figs 23-24). For this reason female reply was discernible faintly, if at all, on oscillograms against the noises. Moreover, in certain cases it was almost inaudible in earphones, still the male perceived it well and demonstrated courtship behaviour [Tishechkin, 2000]. From these experiments it is apparent that the leafhopper vibroreceptors are much more sensitive than the recording equipment. Therefore, here we proceed from the assumption that if our equipment can register the signal, it certainly has sufficient amplitude to be perceived by the insect sitting on the stem to which the gramophone cartridge is attached.

From this it follows that in the habitats with herbaceous vegetation insect vibrational signals can be transmitted successfully from one plant to another both via the stems or leaves and via the roots. Undoubtedly, the insects dwelling on different plant species in mixed thickets can perceive the signals of each other. Consequently, differences in host specialization in small Auchenorrhyncha by no means always provide segregation of vibratory communication channels. As a result, in herbaceous plant communities competition for communication channels exists not only between different species dwelling on the same host, but also between species living on different host plants.

ACKNOWLEDGEMENTS. The study was supported by Russian Foundation for Basic Research (No. 10-04-00275-a).

\section{References}

Michelsen A., Fink F., Gogala M. \& Traue D. 1982. Plants as transmission channels for insect vibrational songs // Behavioral Ecology and Sociobiology. Vol.11. P.269-281.

Tishechkin D.Yu. 2001. Vibrational communication in Cicadellinae sensu lato and Typhlocybinae leafhoppers (Homoptera: Cicadellidae) with notes on classification of higher taxa // Russian Entomol. J. Vol.9. No.4. P.283-314.

Tishechkin D.Yu. 2007. Background noises in vibratory communication channels of Homoptera (Cicadinea and Psyllinea) // Russian Entomol. J. Vol.16. No. 1. P. 39-46. 